\title{
Spanning the Globe - The Plant Phylogeny Poster (PPP) Project
}

\author{
Theodor C. H. COLE ${ }^{1 *}$, Hartmut H. HILGER ${ }^{1}$ (D) , Julien B. BACHELIER ${ }^{1}$ (D) , Peter F. STEVENS ${ }^{2}$, \\ Bernard GOFFINET $^{3}$ (D), Natalia M. SHIYAN ${ }^{4}$ (D) , Svitlana L. ZHYGALOVA ${ }^{4}$ (D) , Sergei L. MOSYAKIN ${ }^{4}$ (D) \\ ${ }^{1}$ Dahlem Centre of Plant Sciences (DCPS), Institute of Biology, Structural and Functional Plant Diversity, Freie Universität Berlin, \\ Altensteinstr. 6, 14195 Berlin, Germany \\ ${ }^{2}$ Department of Biology, University of Missouri-St. Louis, 1 University Boulevard, St. Louis, MO 63121, USA \\ ${ }^{3}$ Department of Ecology and Evolutionary Biology, University of Connecticut, 75 North Eagleville Road, Storrs, CT 06269-3043, USA \\ ${ }^{4}$ M.G. Kholodny Institute of Botany, National Academy of Sciences of Ukraine, 2 Tereshchenkivska Street, Kyiv 01601, Ukraine
}

\begin{abstract}
Historically, wallcharts and posters created by botanical illustrators, often highly skilled artists, have played an important role in teaching botany at the university level. Large-scale panels and posters can visualize complex interrelationships and entire stories in a clear and appealing overview in graphs, tables, and diagrams. Carrying this concept of educational tools into the electronic era, the Plant Phylogeny Poster project uses this approach for displaying evolutionary relationships in systematic botany. The Angiosperm Phylogeny Poster (APP) displays, as phylogenetically arranged clades, the orders and families of flowering plants (with orders hyperlinked to APweb, Stevens, 2001-onwards), the Tracheophyte Phylogeny Poster (TPP) families and genera of ferns and gymnosperms, and the Bryophyte Phylogeny Poster (BPP) orders and families of liverworts, mosses, and hornworts. The portfolio currently also includes about 30 posters on individual orders and families of angiosperms. Each group within these evolutionary trees is matched with essentially relevant morphological features, biogeographic occurrences, and other information in compactly condensed text blocks. All posters are freely available online, some in more than 30 languages, coauthored by a team of more than 130 botanists. The posters are regularly updated, current literature is cited. The project is expanding steadily and rapidly.
\end{abstract}

Keywords: angiosperms, bryophytes, open access, phylogeny, posters, teaching, tracheophytes, wallcharts

Article history. Submitted 02 June 2021. Revised 16 June 2021. Published 29 June 2021

Citation. Cole T.C.H., Hilger H.H., Bachelier J.B., Stevens P.F., Goffinet B., Shiyan N.M., Zhygalova S.L., Mosyakin S.L. 2021. Spanning the Globe - The Plant Phylogeny Poster (PPP) Project. Ukrainian Botanical Journal, 78(3): $235-241$.

*Corresponding author (e-mail: t.c.h.cole@fu-berlin.de)

Botany (as the other life sciences) is largely built on observation and visual documentation, both essential for understanding plants and their structures, as well as for teaching, research, and publishing. Images of plants and their structures drawn on wallcharts and posters by botanical illustrators, who were often skilled professional artists, have played an important role in education, in particular as visual resources for lectures in the life sciences, for illustrating and teaching structure, function, and classification of organisms. Botanical and zoological institutions owned extensive collections of such large-sized wallcharts drawn and painted on canvas or paper, usually fastened to wooden double half-round dowel rods on both ends, and rolled up for storage. The charts were hung in auditoriums and lecture halls for the daily lectures - some huge charts with evolutionary trees ("Stammbäume"), the Periodic Table, or biochemical pathways were even permanently displayed there. Skilled botanical artists were employed at university departments and museums - a highly respected profession of art drawing and lithography having particularly developed in Germany during the $19^{\text {th }}$ century. Many of these beautiful masterpieces (e.g., Fig. 1) have survived over the ages and are preserved as a cultural heritage (Laurent, 2016).

(C) 2021 T.C.H. Cole, H.H. Hilger, J.B. Bachelier, P.F. Stevens, B. Goffinet, N.M. Shiyan, S.L. Zhygalova, S.L. Mosyakin. Published by the M.G. Kholodny Institute of Botany, NAS of Ukraine. This is an open access article under the terms of the Creative Commons Attribution License (http://creativecommons.org/licenses/by/4.0/), which permits use, distribution, and reproduction in any medium, provided the original work is properly cited 

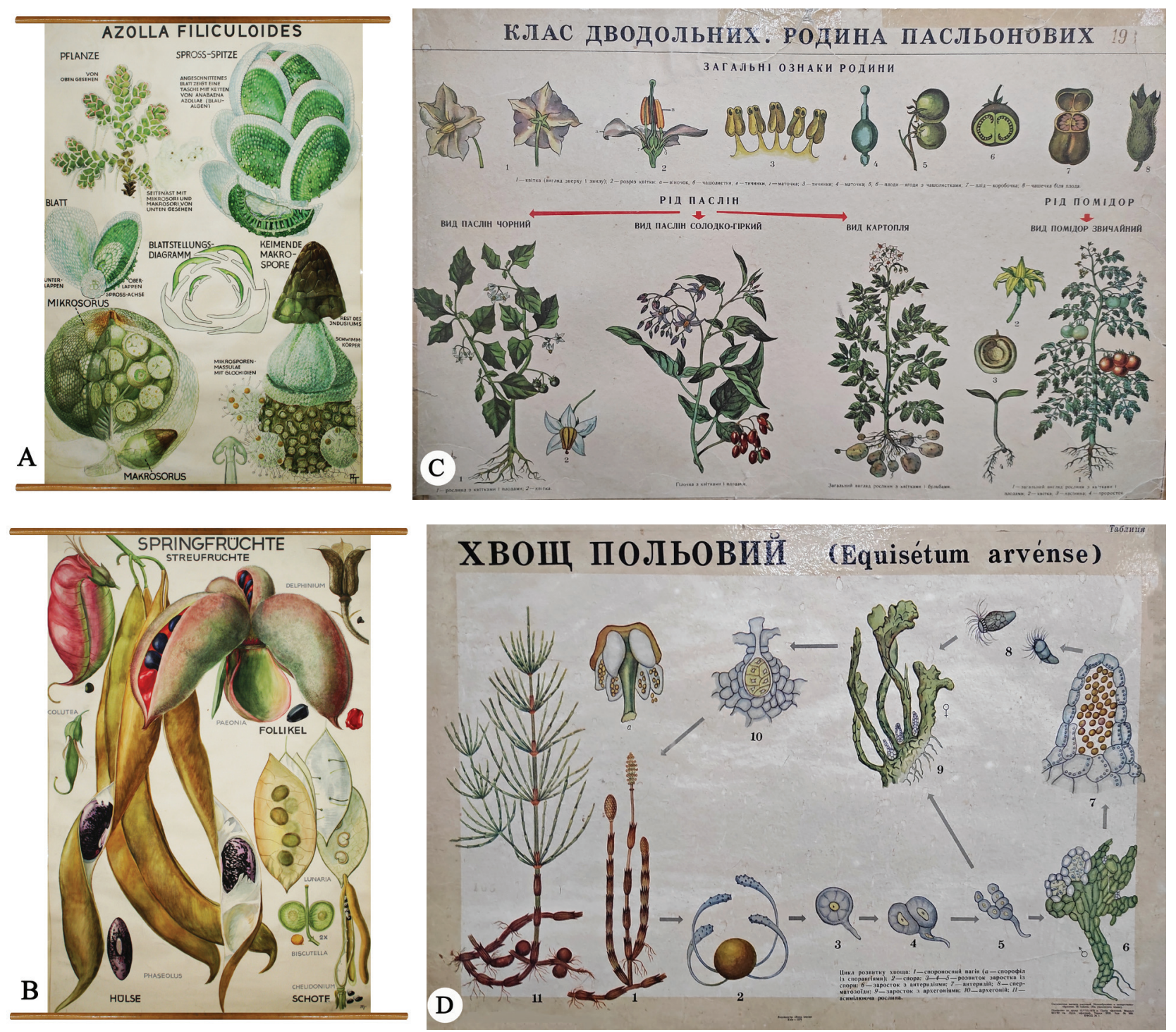

Fig. 1. Botanical wallcharts. A, B: Institute of Systematic Botany and Plant Geography of Freie Universität Berlin, 1950s (A: Azolla filiculoides; B: dehiscent fruits). C, D: Fedkovych Chernivtsi National University, 1970s, publisher "Radianska Shkola" (C: Solanaceae, general morphology; D: Equisetum arvense, life cycle diagram - photographs by Vasyl V. Budzhak)

While with the advent of photography, projected slides soon became the preferred media of choice in teaching, drawings remain important in botany (as by the common quote attributed to the famous $19^{\text {th }}$ century German botanist Julius Sachs in teaching his students: "Was man nicht gezeichnet hat, hat man nicht gesehen" / "What one has not drawn, one has not seen", Scott, 1924: 10). The digital era gave us fascinating new options in graphic design and means for presenting educational materials to students. Courses in graphic design software programs were being offered for members of the university.
Scientists themselves could now create appealing designs and carry out professional typesetting work with basic training or even by self-teaching.

Evolutionary relationships have traditionally been depicted by "family trees", interconnecting hypothetical ancestors with their descendants by a network of "branches" (as prominently exercised by Ernst Haeckel in the $19^{\text {th }}$ century, Fig. 2). For publication of research results, such trees (as any other illustration or photo) must be condensed to fit the restricted space of the layout of a book or journal page, a constraint that leads to smaller 


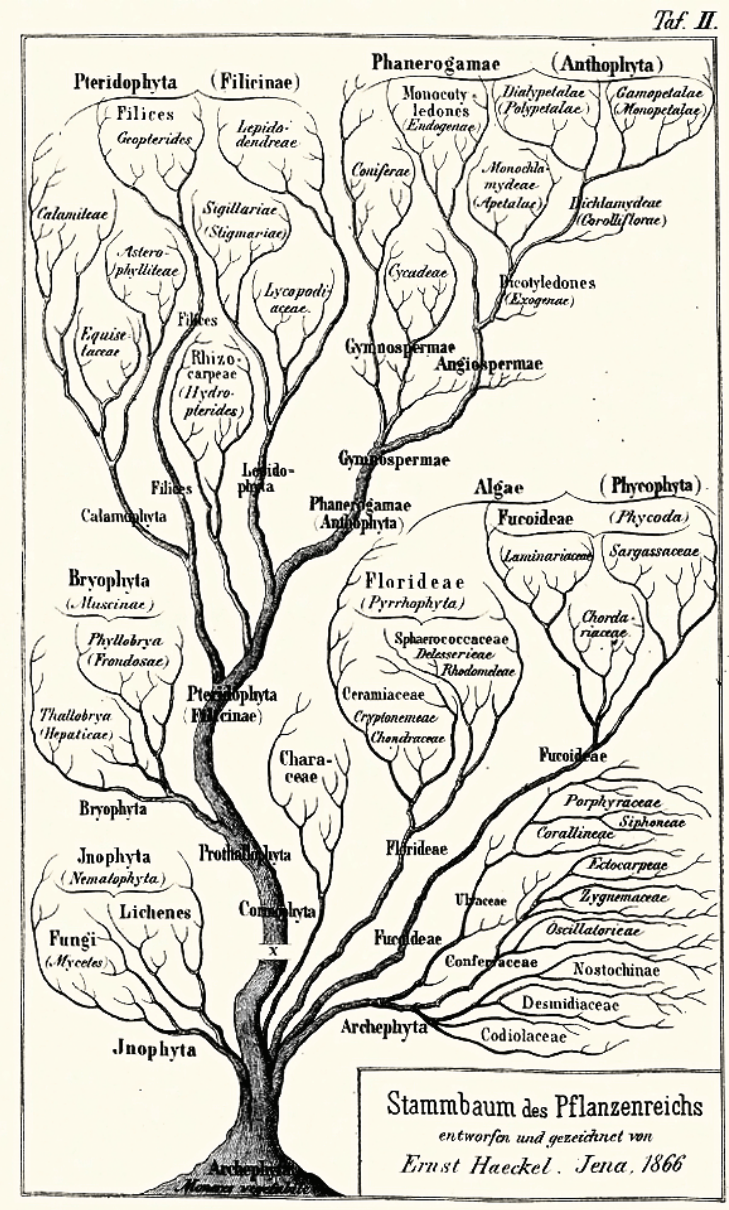

Fig. 2. Ernst Haeckel's historic evolutionary tree of the plant kingdom ("Stammbaum des Pflanzenreichs"); from: E. Haeckel (1866)

and often unreadable text and unrecognizable structures or patterns, thus also limiting the amount of displayable data.

The format of the Plant Phylogeny Posters, however, allows for large-size presentations of family trees providing a clear overview of complex relationships at a glance. In 2005, Theodor C. H. Cole (then lecturer at Heidelberg University and now Honorary Associate with Julien B. Bachelier at the Freie Universität Berlin) devised a "family tree" of angiosperm orders and families in poster format - including relevant features in condensed form - in preparation of teaching a botanical field course for pharmacy students to South Africa. A clear systematic overview of relationships among flowering plant families was needed, yet such a large phylogenetic tree also had to be a compact and transportable teaching tool. This first poster - pasted together as a "hard copy" from cardboard with scissors and glue - was chiefly based on the phylogenetic tree topology from the first two publications of the Angiosperm Phylogeny Group (APG, 1998, 2003; see also APG, 2009, 2016) and the features were taken mainly from Peter Stevens' APweb database (Stevens, 2001-onwards) and the Families and Genera of Vascular Plants (FGVP) series (Kubitzki et al., 1990-2018), among other sources. Together with Hartmut H. Hilger of the Freie Universität Berlin (FU), the first German version entitled POSTER - Systematik der Blütenpflanzen, was published in 2007 by De Gruyter Publishers, Berlin, as a foldable A0-size color print (Cole $\&$ Hilger, 2007).

Peter H. Raven, President Emeritus of the Missouri Botanical Garden, St. Louis, MO, USA (see Raven, 2000; Mosyakin, 2016), encouraged the production of an English version of the Angiosperm Phylogeny Poster (APP) and established the connection to Peter F. Stevens who has become coauthor of several poster titles (Fig. 3; Cole, Hilger, Stevens, 2019). The first electronic version of the APP (in German and English) was made available online on the homepage of the FU Berlin in 2007 and later on ResearchGate in 2012. Further internationalization of the project was triggered with the Chinese version of the APP by Jiang Chen-Kun of Beijing (Peking) University in 2014, which encouraged worldwide expansion, now spanning the globe. Meanwhile, the APP is now available in more than 30 languages.

In circumscriptions of families and orders of angiosperms, our updated APP versions mainly follow the latest version of the APG system (APG IV, 2016), but with necessary amendments and changes that result from recent research data. Also, we take into account the classification schemes provided by expert working groups on various taxa. For example, in recognizing the separate families Amaranthaceae sensu stricto and Chenopodiaceae (which were merged under Amaranthaceae s.l. in all versions of the APG classification) we followed the consensus classification of Caryophyllales accepted by Hernández-Ledesma et al. (2015) and other experts in the group. We also prefer to recognize in Boraginales several separate families (Boraginaceae s.str., Cordiaceae, Ehretiaceae, Heliotropiaceae, Hydrophyllaceae, Lennoaceae, Namaceae, etc.), following Luebert et al. (2016), in contrast to the widely circumscribed Boraginaceae as suggested by APG (see APG IV, 2016, and earlier versions). 


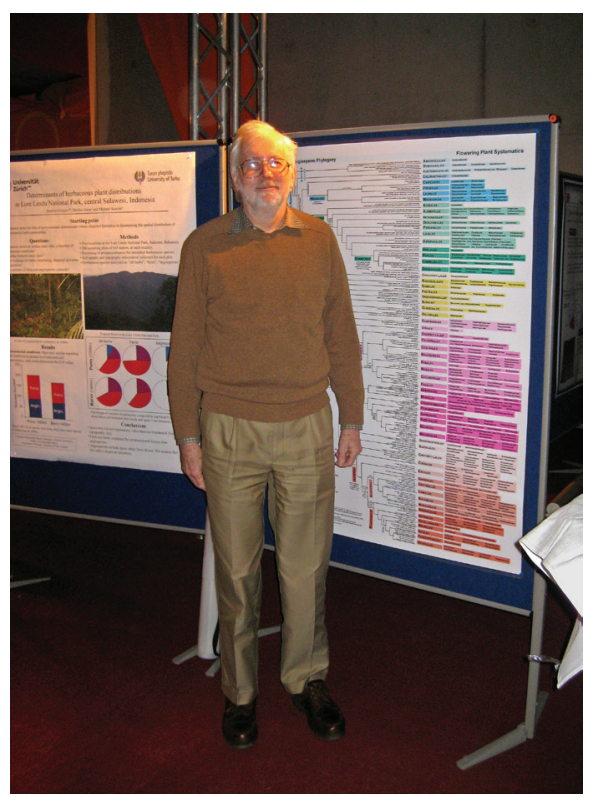

Fig. 3. Peter F. Stevens with the APP at the poster session at BioSystematics 2011 Berlin (Photo by Hartmut H. Hilger)

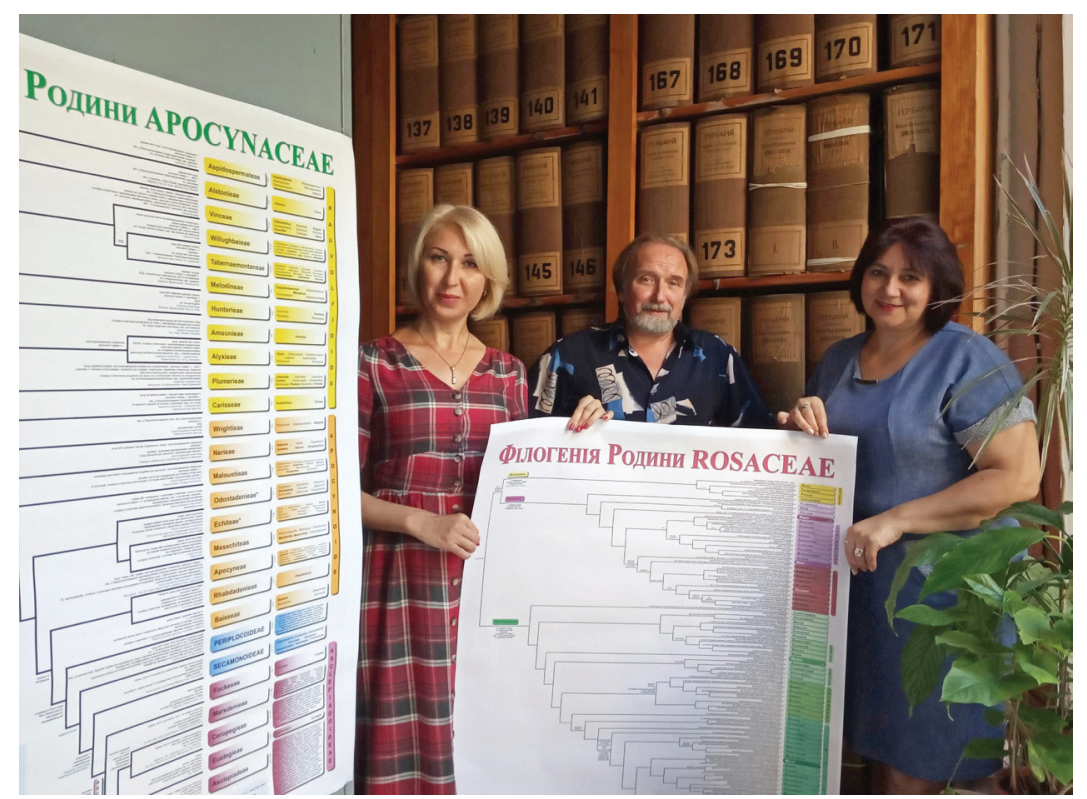

Fig. 4. Two of the Ukrainian plant phylogeny posters displayed by Svitlana L. Zhygalova, Sergei L. Mosyakin, and Natalia M. Shiyan (left to right) at the National Herbarium of Ukraine (KW) of the M.G. Kholodny Institute of Botany, National Academy of Sciences of Ukraine, Kyiv (Photo by Svitlana I. Antonenko)

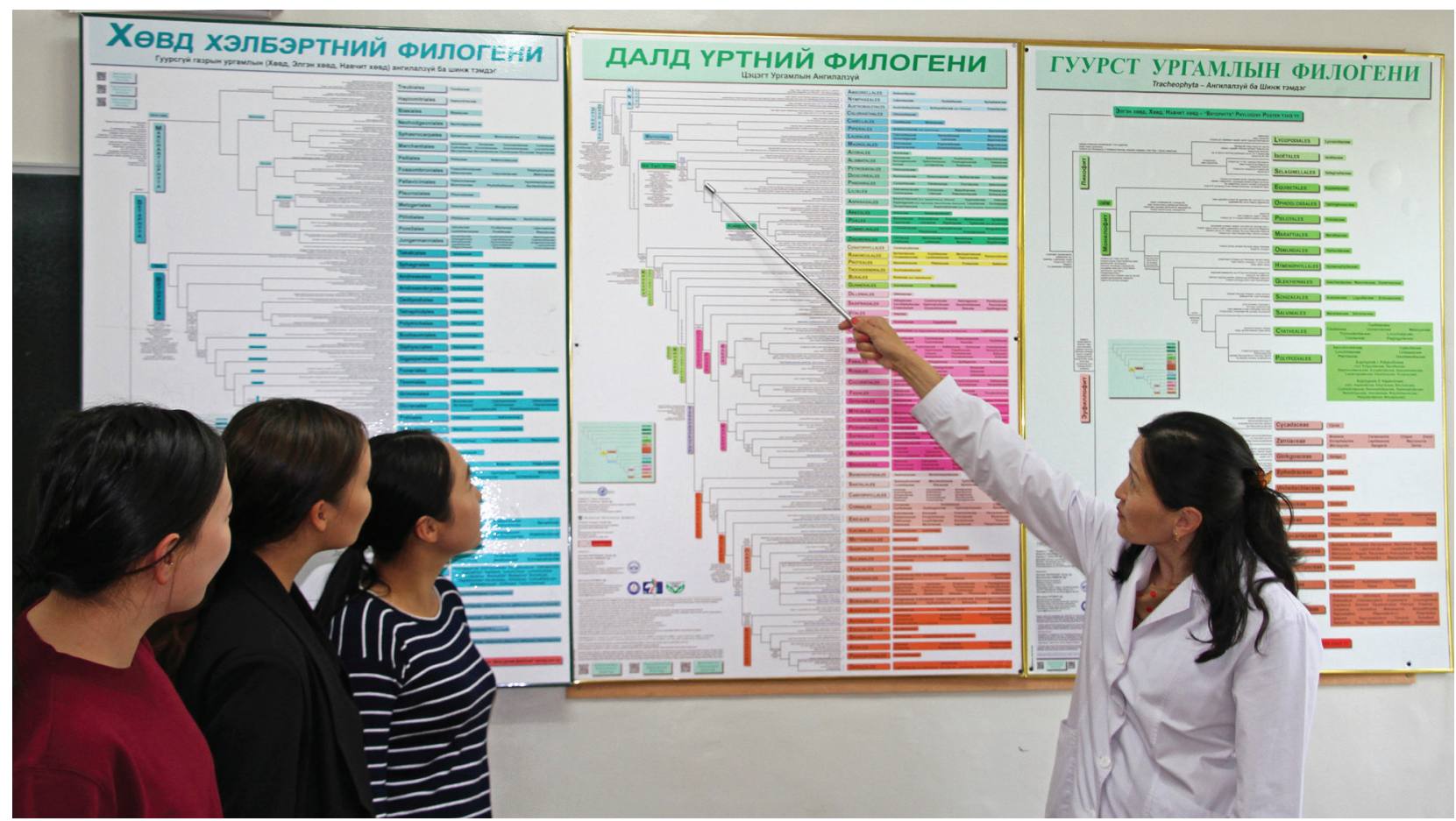

Fig. 5. Dashzeveg Nyambayar teaching plant systematics and evolution at the National University of Mongolia, Ulaanbaatar, using the Mongolian APP, TPP, and BPP which she translated together with Oyuntsetseg Batlai, Urgamal Magsar and Enkhtaivan Enkhjargal (Photo by Oyuntsetseg Batlai) 
The portfolio now encompasses the main trilogy of the APP, TPP (Tracheophyte Phylogeny Poster), BPP (Bryophyte Phylogeny Poster), a general overview of the embryophytes (EMB), and about 30 further posters on individual orders and families of angiosperms, cumulatively involving a team of more than 130 botanists. All posters are available in several languages (see the regularly updated list of all current posters with hyperlinks to each: Cole, 2021).

New collaborators write their translations into a "text extract" sent out to them by the coordinator. Team members are granted full coauthorship for their language versions. The translated texts, once received by the coordinator, are transferred into a template and formatted for uniform layout. After proofreading, the final highquality print PDFs are published on ResearchGate with Digital Object Identifiers (DOIs), some on preprint platforms, and uploaded to the authors' homepages. The advantage of this publishing scheme is the possibility to regularly update the posters based on most recent research.

Since 2016, Julien B. Bachelier, the successor of Hartmut H. Hilger at the Freie Universität Berlin, has become a coauthor of the Tracheophyte Phylogeny Poster (TPP) - meanwhile in 24 languages. In 2018, Bernard Goffinet joined the Bryophyte Phylogeny Poster (BPP) team as a fully co-responsible partner and has since promoted the project by inviting several prominent bryologists - expanding the BPP to currently 20 languages.

All posters are updated regularly according to recent phylogenetic research results, and are freely downloadable from ResearchGate (Cole, 2021) and the webpages of Hartmut H. Hilger at FU Berlin (http://www2.biologie. fu-berlin.de/sysbot/ and https://userpage.fu-berlin.de/ hahilger/). The high-quality print PDFs can be printed in A0 or even larger sizes on professional plotters. Printouts are useful for exhibits, herbaria, lecture halls and seminar rooms. Lecturers may prefer to use the electronic files via projectors to zoom in and out and focus on particular areas moving from one group (taxon or clade) to another.

Several of the Plant Phylogeny Posters have been presented at international conferences and meetings (BioSystematics Berlin, Germany 2011; Monocots VI, Natal, Brazil, 2018; IV International Boraginales Meeting, Florence, Italy, 2018; IAB Bryology Madrid, Spain, 2019; 70 Years of Botanical Garden of Pavol Jozef Šafárik University, Košice, Slovakia, 2020).
Of the meanwhile 268 posters, 59 are in Slavic languages (Russian 20, Ukrainian 19, Czech 6, Slovak 6, Polish 3, Serbian 4, Bulgarian 1). A suite of Czech and Slovak posters is being coordinated by Luboš Majeský and Pavol Mártonfi (Majeský et al., 2020). Since 2016, the Ukrainian and Russian posters have largely been coordinated by Sergei L. Mosyakin, the majority being now implemented and coauthored by Natalia M. Shiyan and Svitlana L. Zhygalova. Anastasiya V. Odintsova of the Ivan Franko National University of Lviv has made a considerable contribution to the first Ukrainian and Russian translations of the APP and TPP, especially in standardizing morphological and some other terms and their matching to English-language equivalents. It should be noted that the task of translating the first Ukrainian and Russian versions of APP and TPP posed some interesting challenges for the Ukrainian collaborators. In several cases it was even necessary to alter or correct the terms that occurred in recent Ukrainian literature, and so this experience with translations was also useful for standardizing the national terminology in the fields of phylogenetic taxonomy and plant morphology. Similar challenges were also met by other team members, resulting in adaptations of the respective national terminology to the internationally recognized standards (mostly based on English, with linguistic roots in classical Latin and Greek).

An additional series of three educational "Language Phylogeny Posters" by T.C.H. Cole and Erika SiebertCole has drawn on recent work in the increasingly popular field of phylolinguistics - the study of the evolution of languages - using, among others, the same phylogenetic methods commonly applied in the life sciences (population genetics, Bayesian Inference, etc.). The series is currently available in 10 languages on ResearchGate. The Ukrainian versions of the three posters have been translated and are coauthored by Andrey V. Podgurenko (Андрій В. Подгуренко), formerly Department of Foreign Languages, Petro Mohyla Black Sea National University, Mykolaiv, Ukraine (Кафедра романогерманської філології, Чорноморський національний університет імені Петра Могили, Миколаїв, Україна) (Cole et al., 2020).

As free online educational resources the posters are extensively used in teaching and as a reference for research at universities and herbaria worldwide (Figs. 4, 5). The project is growing steadily with new titles and versions in different languages. 


\section{References}

APG (Angiosperm Phylogeny Group). 1998. An ordinal classification for the families of flowering plants. Annals of the Missouri Botanical Garden, 85: 531-553. https:// doi.org/10.2307/2992015

APG II. 2003. An update of the Angiosperm Phylogeny Group classification for the orders and families of flowering plants: APG II. Botanical Journal of the Linnean Society, 141: 399-436, https://doi.org/10.1046/j.1095-8339.2003. t01-1-00158.x

APG III. 2009. An update of the Angiosperm Phylogeny Group classification for the orders and families of flowering plants: APG III. Botanical Journal of the Linnean Society, 161: 105-121, https://doi. org/10.1111/j.1095-8339.2009.00996.x

APG IV. 2016. An update of the Angiosperm Phylogeny Group classification for the orders and families of flowering plants: APG IV. Botanical Journal of the Linnean Society, 181: 1-20, https://doi.org/10.1111/boj.12385

Cole T.C.H. 2021-onwards. Plant Phylogeny Posters (PPP) poster titles and languages with links. Available at: https:// www.researchgate.net/publication/344193089_Plant Phylogeny Posters PPP - poster titles and languages with links

Cole T.C.H., Hilger H.H. 2007. Systematik der Blütenpflanzen: Stammbaum der Angiospermen [Poster]. Wandkarte. Berlin, New York: de Gruyter, ISBN 978-3-11-020066-9.

Cole T.C.H., Hilger H.H., Stevens P.F. 2019. Angiosperm Phylogeny Poster (APP) - Flowering plant systematics, 2019. PeerJPreprints, 7e2320v6. https://doi.org/10.7287/ peerj.preprints. $2320 \mathrm{v} 6$

Cole T.C.H., Siebert-Cole E., Podgurenko A.V. 2020. Henealohichni dereva mov [Poster].[Коул Т.К.Г., ЗібертКоул Е., Подгуренко А.В. 2020. Генеалогічні дерева мов. Постер]. http://dx.doi.org/10.13140/RG.2.2.15203.17449

Haeckel E. 1866. Generelle Morphologie der Organismen. [Band 2: Allgemeine Entwicklungsgeschichte der Organismen, Berlin, Boston: De Gruyter, 2020]. https:// doi.org/10.1515/9783111419336

Hernández-Ledesma P., Berendsohn W.G., Borsch T., von Mering S., Akhani H., Arias S., Castañeda-Noa I., Eggli U., Eriksson R., Flores-Olvera H., FuentesBazán S., Kadereit G., Klak C., Korotkova N., Nyffeler R., Ocampo G., Ochoterena H., Oxelman B., Rabeler R.K., Sanchez A., Schlumpberger B.O., Uotila P. 2015. A taxonomic backbone for the global synthesis of species diversity in the angiosperm order Caryophyllales. Willdenowia, 45(3): 281-383. https://doi.org/10.3372/ wi.45.45301
Kubitzki K. et al. (eds). 1990-2018. Families and genera of vascular plants (FGVP), vols. 1-15. Berlin; Heidelberg; Cham, etc.: Springer. https://www.springer.com/ $\underline{\text { series } / 1306}$

Laurent A. 2016. The Botanical Wallchart: Art from the Golden Age of scientific discovery. Chicago: University of Chicago Press, 224 pp.

Luebert F., Cecchi L., Frohlich M.W., Gottschling M., Guilliams C.M., Hasenstab-Lehman C.E., Hilger H.H., MillerJ.S., MittelbachM., Nazaire M., Nepi M, Nocentini D., Ober D., Olmstead R.G., Selvi F., Simpson M.G., Sutorý K., Valdés B., Walden G.K., Weigend M. 2016. Familial classification of the Boraginales. Taxon, 65(3): 502-522. https://doi.org/10.12705/653.5

Majeský L., Mártonfi P., Cole T.C.H. 2020. Plant Phylogeny Posters - providing clear and concise overviews of plant phylogeny. In: Mártonfiová L, Suvák M, Mártonfi P (eds) Book of Abstracts. Conference 70 Years of Botanical Garden of Pavol Jozef Šafárik University (Slovakia, Košice, 3-4 Sep. 2020): The History and the Present of the Botanical Research and Nature Conservation. Pavol Jozef Šafárik University in Košice, p. 22. https://doi. org/10.33542/BOA2020-879-8

Mosyakin S.L. 2016. The knight of biodiversity. The $80^{\text {th }}$ anniversary of Peter Hamilton Raven. Visnyk of the National Academy of Sciences of Ukraine, [vol. of 2016], No. 6: 95-101. [Мосякін С.Л. 2016. Лицар біорізноманіття. До 80-річчя Пітера Рейвена. Вісник НАН Украӥни, о. 6: 95-101].

Raven P.H. 2000. Primary producers. In: Newbold H. (ed.). Life stories: world-renowned scientists reflect on their lives and on the future of life on earth. Berkeley, Los Angeles, London: University of California Press, pp. 28-41.

Scott D.H. 1925. German reminiscences of the early 'Eighties', New Phytologist, 24(1): 9-16. https://doi. org/10.1111/j.1469-8137.1925.tb06645.x

Stevens P.F. 2001-onwards. Angiosperm Phylogeny website (APweb). Available at: http://www.mobot.org/MOBOT/ research/APweb/

Recommended for publication by G.V. Boiko 
Коул Т.К.Г., Хільгер Х.Х., Башельє Ж.Б., Стівенс П.Ф., Гоффіне Б., Шиян Н.М., Жигалова С.Л., Мосякін С.Л. 2021. Об'єднуючи світ - Проект постерів з філогенії рослин. Украӥнський ботанічний журнал, 78(3): 235-241 [In English].

Далемський центр дослідження рослин, Інститут Біології, Вільний університет Берліна, Альтенштейнштрассе 6, 14195 Берлін, Німеччина: Т.С.Х. Коул, Х.Х. Хільгер, Ж.Б. Башельє. Відділ біології, Університет Міссурі-СентЛуїс, Університетський бульвар 1, Сент-Луїс, Міссурі, 63121, США: П.Ф. Стевенс. Відділ екології та еволюційної біології, Університет Коннектикуту, Північний Іглвіл-роуд 75, Сторрс, Коннектикут, 06269-3043, США: Б. Гоффіне. Інститут ботаніки імені М.Г. Холодного, НАН України, вул. Терещенківська 2, Київ 01601, Україна: Н.М. Шиян, С.Л. Жигалова, С.Л. Мосякін.

Реферат. Традиційно, настінні графіки та плакати, створені ботанічними ілюстраторами, а часом і професійними художниками, відіграють важливу роль у вивченні ботаніки в університетах та інших навчальних закладах. Масштабні панно та плакати можуть візуалізувати складні та історичні взаємозв'язки у чіткому та естетичному вигляді через графіки, таблиці та діаграми. Використавши дану освітню концепцію в умовах сучасної електронної епохи, проект "Плакати 3 філогенії рослин" застосовує підхід візуалізації для відображення еволюційних взаємозв'язків у сучасній ботанічній систематиці. Плакати з філогенії покритонасінних (Angiosperm Phylogeny Poster - APP) відображають сучасні філогенетичні співвідношення і взаємозв'язки між кладами, порядками та родинами квіткових рослин (із посиланнями на APweb, Stevens, 2001-onwards), плакат з філогенії судинних рослин (Tracheophyte Phylogeny Poster - ТРP) крім іншого - родів папоротей і голонасінних, а плакат $з$ філогенії мохоподібних (Bryophyte Phylogeny Poster - BPP) - родин печіночників, мохів та антоцеротів. На тепер в активі проекту нараховується близько 30 плакатів вибраних порядків та родин покритонасінних. Особливістю цих філогенетичних дерев $\epsilon$ те, що їхні окремі групи характеризуються систематично важливими морфологічними ознаками, біогеографічними даними та іншою інформацією, поданою в компактних блоках тексту. Усі плакати розміщені у вільному доступі в Інтернеті, ряд з них перекладені 30 мовами, завдяки команді 3 понад 130 ботаніків світу. Плакати регулярно оновлюються, в них цитуються актуальні літературні джерела. Проект неухильно та швидко розширюється.

Ключові слова: відкритий доступ, мохоподібні, філогенія, навчання, плакати, покритонасінні, судинні рослини, таблиці 